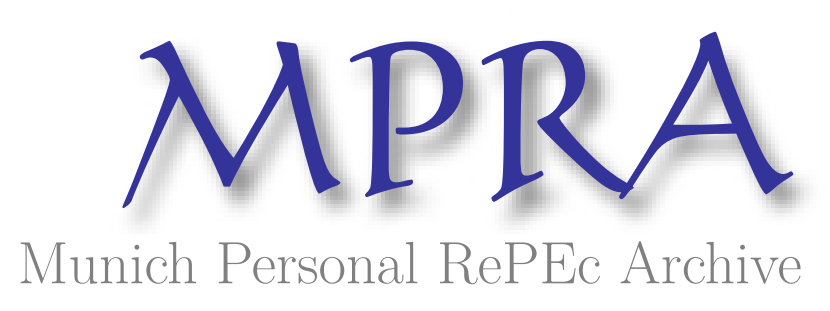

\title{
The Economic Development of China
}

Levy, Brandon

24 July 2012

Online at https://mpra.ub.uni-muenchen.de/45067/

MPRA Paper No. 45067, posted 18 Mar 2013 20:15 UTC 


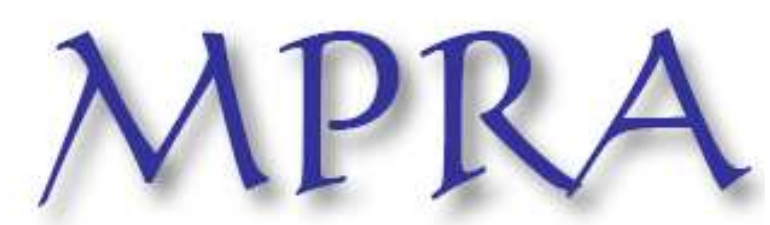

Munich Personal RePEc Archive

\title{
The Economic Development of China
}

\author{
Brandon Levy
}

24. July 2012

Online at http://mpra.ub.uni-muenchen.de/45067/ MPRA Paper No. 45067, posted DEVELOPMENT 


\section{ABSTRACT}

Prior to the early part of the $19^{\text {th }}$ century, China's economy had long been superior to that of the West's. The Chinese's ability to utilize science and technology had been instrumental in leading their enormous population to economic prosperity and for a while, superiority. During the $18^{\text {th }}$ century European science and technology surpassed that of the Chinese. It is my contention that a variety of Chinese contributions expedited Europe's prolific economic development and aided in its expansion. Perhaps with the assistance of innovations derived from China, the European economy was able to forge ahead of China's economy. In addition to the Europeans developments there were several other contributing factors that led to the fall of the Chinese economy. Using historical background the latter part of this paper aim's to explain the rapid growth that has recently occurred in China. In spite of substantial adversity, China has re-emerged as one of the most dominant economic forces in the world. To begin I will use historical background in an attempt to explain what China was able to contribute, both directly as well as indirectly to the development of Europe. It is also my objective to explain that a distinct correlation exists between Europe's rapid economic growth and the fall of China during the $18^{\text {th }}$ century.

\section{INTRODUCTION}

Prior to attempting to explain the long and rich history of the Chinese, it is important to lay the appropriate groundwork. A fundamental difference between the Chinese and the Europeans was and always has been their philosophical belief systems. This is an important piece of the puzzle concerning why Europe was able to develop so rapidly and why China's economic prosperity ended just as fast. It was no doubt the philosophical or spiritual beliefs that most often guided the decisions of the influential Chinese and European leaders. It was those belief systems that led to decisions that subsequently shaped history. Obviously it is not feasible that entire populations of people could share the exact same spiritual philosophy. However, the Chinese main philosophy was Confucianism while the majority of Europeans believed in Christianity (Kang 2010, 25).

\section{CONFUCIANISM}

Confucianism is a belief system that is based on the teachings of Confucius. Confucius lived in China from 551 to 479 B.C. Confucianism can also be described as a philosophy model of human society and life (Kang 2010, 25-26). The idea of establishing such a system was because Confucius was troubled by the society in his life which was at the time period in China's history marked by political instability and wars. A main component of Confucianism is virtues, such as respect, loyalty, honesty, hard work, politeness and generosity. Confucianism wants everyone to practice such virtues in order for the development of the harmonious society and a united peaceful China (Lockard 2009, 28-29). The Confucian code of conduct also calls for the observation of relationships. The superior must set a good example and the inferior must be obedient as well as submissive. Confucius created such a practical system of social hierarchy that many still follow it today. A prime example of Confucianism is the relationship between supervisors and employees. Another is the relationship between teachers and their students. Similarly, Confucius outlined basic relations in society that everyone needed to follow and observe. The first relationship is ruler over subject. The second is parent over child. The third relationship outlined is husband over wife. The fourth is older sibling over younger sibling. The fifth and final relationship that Confucius outlined was older friend over younger friend (SACU 2001). In addition, Confucianism encourages paying back other people for their assistance and their kindness. Another teaching of Confucius was that the elderly 
have accumulated a lot of wisdom from life experiences and thus, should be treated with great reverence and respect. It was important that the elderly be honored by the young. This teaching unquestionably differentiated from the European perspective on social relations which largely relied on a class system. The impact of Confucius teachings in China are so widespread that his code of conduct can be described as China's code of conduct. This is because almost all Chinese live by the Confucian code of conduct. It is visible in China's form of government. China has never succumbed to Democracy because that would imply that a younger person's vote is equal to the vote of a wise elder. Confucius teachings imply that elders make natural leaders and can set good examples.

"It was arguably the Tang dynasty (a.d 618907) that made perhaps the most direct advances in governance, introducing a key institutional experiment that reflected these Confucian ideas: a government run by talent, not heredity, with civil servants selected through a public competition assessing candidates' qualification, open (in theory) to all males and held at regular, fixed intervals" (Kang 2010, 31).

From its inception, Confucianism has made not only a huge, but lasting impression on Chinese society. Over the years it has had a positive impact and more or less achieved Confucius' goal of developing a peaceful and harmonious society in China that is not constantly at war.

\section{THE TRIBUTE SYSTEM}

Maybe the most important aspect of the rise of the Chinese economy was how the country conducted international diplomacy. Fundamentally, the Chinese realized relatively early on that war did not benefit anybody. Eastern Asian nation states adopted a ranking methodology by the $14^{\text {th }}$ century known as the tribute system. The tribute system was a ranking system that, based on a variety of factors, determined the hierarchy of each nation state. Not all historians and scholars have been able to come to a consensus as to the extent or scope of tribute systems; most do believe that some arrangement, albeit formal or informal was used. It is clear that the Eastern Asian nation states were able to conduct themselves in such a manner that minimized war. "In fact, from 1368 to 1841 - from the founding of the Ming dynasty to the Opium wars between Britain and China - there were only two wars between China, Korea, Vietnam, and Japan: [ . . .]" (Kang 2010, 2). The system allowed the states to know where they stood in relation to each other. Military size and technology were among the factors that allowed China to dominate the region. By utilizing the tribute system many of the complications associated with international diplomacy were alleviated. For all of the nation states that abided by the arrangement, peace and prosperity proved tribute systems to be effective regarding diplomatic relations.

\section{AGRICULTURE}

Chinese inventions were often "laborsaving" because of the large amounts of food that would be necessary to produce in order to feed such a large population (Needham 2004, 61). Again, pointing out the wheelbarrow as a perfect example. In China the abundance of food production was paramount in keeping the price of food low. Consequently, inexpensive food raised the standards of living for the Chinese. The sizeable population had not been an issue for ancient China because of the attention that government gave the agriculture.

"Of course in dealing with economic problems different dynasties in China devised different schemes. Yet in as much as certain background factors underwent little change, a number of common features in administration became perennial. One such feature was a vigorous and persistent promotion of agriculture by the State, virtually uninterrupted for 2,000 years" (Needham 2004, 50). 
Each dynasty recognized the importance of agriculture and aggressively disseminated the message.

\section{CHINESE IMPERIALISM}

Imperialism in China did not begin until the $3^{\text {rd }}$ Century BCE. In 221 BCE Qin Shi Huang was able to destroy the other six states in the region and unite China. By conquering and unifying all seven states in the region, Qin Shi Huang was recognized as the first emperor of China. Qin Shi Huang introduced common coinage as well as a unified system of weights and measures. China's first emperor even standardized the sizes of axels on carts that traveled on the Chinese roads. The Chinese have a long history of brilliant innovations and discoveries. Perhaps, it was the first emperor who introduced the people of China to the prosperity that accompanied technology and innovation. China, being one of the world's oldest civilizations has contributed a lot to the West. In Science and Civilisation in China (2004), Joseph Needham listed some of China's most noteworthy contributions to the West as well as the West's approximate lag in centuries behind China. "In case after case it can be shown with overwhelming probability that fundamental discoveries and inventions made in China were transmitted to Europe, [. . .]" (Needham 2004, 20). Some of the more extraordinary contributions Needham listed were gunpowder, paper, cast-iron, magnetic compass used for navigation, the crossbow, wheelbarrow and porcelain. Needham went on to list over 250 items invented by the Chinese (Needham 2004, 223).

\section{EARLY CHINESE INNOVATIONS}

The wheelbarrow is a prime example of Chinese innovation. The wheelbarrow was not known to be utilized in the West until the 1400's, while it had been common in China since the $3^{\text {rd }}$ century (Needham 2004, 4).
Another quality that the wheelbarrow possess' is that it was used as a labor-saver. It often appears that the Chinese would find a way to accomplish their goal that did not include practicing chattel-slavery. It was most likely the Chinese people's ability to innovate and discover ways to increase productivity that enabled their economy to thrive before Europe's. It was perhaps through innovation that labor-saving technology kept slavery from becoming a foundation for Chinese society. Slavery, unlike technology was extremely prevalent in Europe during the medieval period (Needham 2004, 227-228).

The ceramics that were produced by the Chinese in the $16^{\text {th }}$ century were especially attractive to the Europeans largely because of the brilliantly colored glaze finishes (Needham 2004, 113-114). Aeneas Anderson was one of the 84 men who accompanied Lord Macartney on his famous 1793 mission to China. In one of his letters sent back to Europe, Anderson commended China's porcelain: “There are no porcelain shops in the entire world which can compare in size, richness or delivery with those in Canton" (Elman 2006, 80). It is apparent by Anderson's enthusiasm that Europeans envied China's wares. The premium quality of the ceramics from China spawned a wonderful reputation not only throughout Europe but the entire World. The phrase "fine China" was forever synonymous with high quality plate ware. Chinese porcelain was so highly sought after that many European's tried, with little initial success to replicate it. The European chemists did not give up very easily and in 1750 they had finally figured out the Chinese' secret to making quality ceramics (Elman 2006, 8081). Consequently, the once extremely lucrative Chinese porcelain industry suffered, while simultaneously improving the Europeans standard of living. Porcelain is a good example of how Chinese technology was able to 
contribute to European development. Porcelain, while only one good, clearly illustrates how it was possible that European success directly correlated to China's economic downfall.

Paper and printing are undeniably two of China's greatest contributions to Europe as well as the rest of the World. China was the first nation in the world to have its own national currency (Needham 2004, 55). The Chinese were also the first people to develop wall paper as well as the first to make toilet paper. Perfumed toilet paper was documented as being manufactured for the imperial family as far back as 1393 (Needham 2004, 205). The contribution of printing by the Chinese to the West, helped to launch the Reformation and the revival of learning (Needham 2004, 53). Europe owes China an enormous amount of gratitude, or at least recognition for its printing contribution.

In the West, especially in Europe, patents were an important process. Given the long list of innovations, it was unfortunate for the Chinese that they did not know anything about patents (Needham 2004, 224). The Chinese were very innovative people, constantly using technology to elevate their living standards. "China has the longest unbroken history of progress in science and technology (over 4,000 years) of any nation in the world" (Needham 2004, 224). However, the Chinese did not maximize the capabilities of all of their innovations and discoveries. A possibly causality could be that China did not foster an environment that was conducive to the entrepreneurial spirit. "Inventions in themselves, however, do not foster or inhibit science" (Needham 2004, 225). Despite China being more technologically advanced than the West for so many centuries, Needham believed one of the many reasons that China had not ever experienced an industrial revolution was because many of the Chinese inventions were used mainly for the amusement of the emperor rather than moving an economic society forward.

A perfect example would be how gunpowder was primarily used as entertainment in firework displays for the Imperial court. The innovation of gunpowder did not have the same effect on China as it did on Europe. Europeans quickly embraced the discovery and utilized it as a tool for destruction. "The strange thing is that China was able to absorb these earth-shaking discoveries and inventions while Europe was gravely affected by them" (Needham 2004, 53). Needham also thought that the European social class system played a big part in the Industrial Revolution originating in the West (Needham 2004, 230-231). Europe's social class system of feudalism would ultimately prove instrumental in the rise of modern science in Europe. In Imperial China a social class system was not as prevalent as it was in the West. "The Chinese had the inventiveness, but lacked the social conditions for the elaboration of modern science" (Needham 2004, 14).

Though modern opinion is beginning to change, many historians, especially European historians accredit the British imperial dominance of China to the technological supremacy of the Europeans. It is true that modern science and technology propelled the Europeans ahead of China. But, the contributions made by China bridged the gap for the Europeans (Needham 2004, 231).

\section{BLACK DEATH}

During the $14^{\text {th }}$ century a plague known as Black Death, would undeniably change the world. Black Death was one of the most devastating contagions that man had ever experienced. The first outbreak of the plague was believed to have originated in China in the 
early 1330's. Trade between Asia and Europe had been increasing considerably, and in 1347, ships thought to be infested with rats from China reached Sicily. The ship's had brought the disease with them. Since Italy was the epicenter of European trade and politics, this provided an ideal opportunity for the disease to spread. The plague, being carried by the rats, was conveyed to humans by the fleas that were living on the rats. The plague hit cities first and then quickly infected the rural regions. The Black Death spread so quickly, by 1350 onethird of all Europeans were dead (McHenry 1992, 297-298).

The plague did not discriminate amongst the social classes; many of the European rulers were dead. Ultimately the plague allowed the wealthiest European's the opportunity to gain control of their country. The wealthy and educated Europeans quickly seized control. The feudal system established in Europe made the transition of power almost natural. "The Black Death struck not only Western Europe but also the Mongol Empire, including China where it had originated. But in China no bourgeois arose to take control" (Needham 2004, 230). There were several predominant reasons why there was never a bourgeois revolution in China. Primarily, the Chinese had long benefitted from a stable government as well as the establishment of bureaucracy (Needham 2004, 231-232).

The plague which had originated in China changed Europe forever. A claim can be made that inadvertently, China contributed to European prosperity by reducing its population. Black Death more than just devastated medieval Europe; it caused significant economic and social changes in all areas of the world (Needham 2004, 230). Fernand Braudel, an economic historian determined that it was in fact Black Death that had intensified the recession that had been going on since the turn of the century in the European economy (Braudel 1984, 78). The severity of the recession caused economic and societal changes to significantly speed up between 1350 and throughout the 1400's.

The power once possessed by the church had deteriorated. The role that the church played in society had also changed. The plague had decimated so many that a large number of Europeans began to question their faith in the church. Acclaimed sociologist Immanuel Wallerstein believed that the collapse of the church was one of the four elements that led to the European bourgeoisie gaining and then keeping power (Needham 2004, 229). Killing such a large number of people, Black Death radically transformed the workforce in Europe. The severe labor shortage brought on by the plague drastically affected the economy. Labor was in high demand and subsequently, commanded higher wages. In 1351 England's King Edward III instructed his parliament to establish the Statute of Labourers, a policy designed to freeze wages during the labor shortage. Further turmoil ensued in response to the wage caps that were put in place. The plague that originated in China ultimately changed the European, as well as the world economy forever.

\section{THE JESUITS}

The Jesuits began arriving in China during the latter part of the Ming Dynasty, around the 1580's. This time period in China was one of great economic prosperity as well as governmental disarray. "Michele Ruggieri (1543-1607), for example, entered Macao in 1579 and initiated a Chinese mission in 1582" (Elman 2005, 64). The Jesuits mission in China was twofold. The Jesuits primary objective while in China was to convert the Chinese to Christianity. However, with them they had brought the understanding of 
European science and technology. From the onset the missionaries assumed that European science and technology would surely be far more advanced than anything that the Far East had previously been exposed to. "Europeans increasingly thought themselves scientifically and technologically superior to others after 1500, but neither the Chinese nor Japanese agreed with this perspective [. . .]" (Elman 2006, 11). Initially the Jesuits had believed that their superior knowledge would aid them in converting the Chinese to Christianity. The early Jesuits categorically underestimated the skepticism of the Chinese. "Ruggieri introduced European mathematics, mechanical clocks, and prisms to gain favor among local elites near Guangzhou" (Elman 2005, 64). The latter Ming and early Qing governments experienced a mutually beneficial relationship with the Jesuits.

Among other things, the Chinese emperors received intellectual insight from the Jesuits regarding cosmology and mathematics that led to a monumental breakthrough in calendar reform. It was only because of the Jesuits understanding of Western science and technology that they were ever permitted in China in the first place. While in China spreading their spiritual beliefs, the Jesuits had the opportunity to learn many new things. Surely, the Jesuits conveyed their newly acquired knowledge to scholars back in Europe. It is well documented that the Jesuits introduced European ideas to the Chinese. What is not as clear is, while on their mission to China, exactly how much new information the Jesuits were able to transfer back to Europe. A classic example of this type of knowledge transfer would be when Michael Piotyr Boym, a Jesuit who served the Southern Ming in the 1650's, took the Map of the Middle Kingdom (Zhongguo tu), circa 1652 back to Rome in 1656. "The original manuscript conveyed Jesuit knowledge of China to Europe" (Elman 2005, 130). It is difficult to quantify with any level of certainty, how much the Chinese contributed to the European Jesuits later scientific discoveries. An impressive list of relevant discoveries makes it is obvious that the Chinese have an outstanding history of innovation. It makes intuitive sense that the Jesuits would often, intentionally or not, fail to credit the Chinese for knowledge that they transferred back to Europe. Language barriers made history difficult to pass down accurately. Often words did not precisely translate from one language to the other. Given our present day understanding of language it is reasonable to contend that a lot of information, especially intricate details more than likely could have been lost in translation. China certainly, at least for a short time, benefitted from European science and technology. What has always been less evident is that the Europeans, while in the Far East, were simultaneously gaining an equal amount of knowledge from the Chinese.

The Chinese intellectuals were undoubtedly interested in capitalizing from the Jesuits understanding of the physical sciences. However, they grew tired of the religious message that accompanied the European Jesuits. The Chinese acknowledged and appreciated the utility of Western science but had no interest in expanding on, or developing any open trade policy with the Europeans.

"The Ming and Qing imperial court induced Jesuit mathematical, astronomical, military, and mensuration experts to work as minions in the government bureaucracy to augment each dynasty's own project of political and cultural control. Consequently, it would be a mistake to underestimate Chinese efforts to master on their own terms the Western learning of the Jesuits in the sixteenth, seventeenth, and eighteenth centuries" (Elman 2006, 13). 
It was only fitting that Benjamin A. Elman, a professor of East Asian Studies at Princeton titled his 2005 book on science in China, On Their Own Terms. Elman's choice of title fit seamlessly with the mentality of the Chinese intellectual elite during the early part of the Qing Dynasty. The Chinese appreciated the knowledge shared by the Jesuits from the West. However, while appreciative they did not feel obligated to extend the Europeans any further courtesies. Many of the Chinese scholars shared the mentality of "thanks, but we will take it from here".

\section{EUROPEAN IMPERIALISM IN CHINA}

Prior to the $19^{\text {th }}$ century China was a very self-sufficient nation. China's strong markets had put the nation in a position of economic prosperity. The English continued to use science and religion as their primary means of diplomacy. Through those channels they were hopeful that China would eventually agree to open international trade that was not so deeply regulated. "British Protestants-secular and religious- perceived the Qing empire as an obstacle to open commerce and Christian evangelism" (Elman 2006, 100). While expansion of trade would benefit both nations, the Europeans had more to gain from trade with China.

Since the eighteenth century, the Chinese government had enacted severe limitations on foreign trade, and was both apprehensive and disapproving of foreigners. Direct oceanic trade between China and Europe began during the sixteenth century. At first trade was led by the Portuguese and the Spanish. They brought silver to China from the Americas to trade for silk. Later the Spanish and Portuguese were joined by the British and Dutch. Originally trading took place at several ports all along the Chinese coast, but gradually the Chinese government restricted Western trade to only one port, Canton. The port at Canton was the only market open to foreign commerce. The Chinese preferred to limit international trade to one port so that the government could more easily collect taxes (Tagliacozzo 2011, 234-235). The Cohong were a group of merchants licensed by the Chinese whom were granted exclusive trading rights to deal with the Westerners. For the British side, the East India Company, granted approval from the King, similarly had a monopoly of trade with both India and China. The E.I.C. purchased silks and tea from the Chinese but did not have that much to offer in return except for silver.

For many years this system was acceptable to both the Chinese and the Europeans. As the demand for tea increased and the Industrial Revolution led the Europeans to expand their manufactured goods into more markets, the British began to try to expand their trade opportunities in China. The British assumed that they were going to establish Western-style diplomatic relations with the Chinese. As stated earlier, the Chinese had historically utilized a tribute system with all issues pertaining to international diplomacy. The Europeans attempted to use Western-style diplomacy to expand trade with China. The most famous attempt by the British to expand European trade with China was made by Lord Macartney in 1793. Professor Immanuel Chung-Yueh Hsu, a scholar of modern Chinese intellectual and diplomatic history at the University of California at Santa Barbara outlined Lord Macartney's mission to China. Macartney's mission had six main objectives:

1. To acquire one or two places near the teaand silk-producing and the woolenconsuming areas, where the British traders might reside and English jurisdiction be exercised. 
2. To negotiate a commercial treaty with a view to extending trade throughout China if possible.

3. To relieve existing abuses at Canton.

4. To create a desire in China for British products.

5. To arrange diplomatic representation at Peking.

6. To open Japan, Cochin China, and the Eastern Islands to British commerce (Hsu 1995, 156-157).

The British led European Imperialists desperately wanted to have some sort of social, economic or political influence in China ( $\mathrm{Hsu}$ 1995, 155). For a long time the Europeans did not have anything that the Chinese viewed to have exceptional value. China did not have the desire nor need to adopt European technology. "In 1793, when the British envoy Lord Macartney arrived in China and proposed the opening of trade, Emperor Qianlong famously replied, 'We possess all things. I [. . .] have no use for your manufactures" " (Vogel 2011, 695). It was not until the Europeans imperialized India that they discovered their opportunity to permeate the Chinese markets. India was rich with opium, which would turn out to be extremely lucrative for the Europeans.

Opium became instrumental in affording Europe the opportunity to exalt its influence in China. Opium had previously been available in China despite being officially prohibited by Emperor Yongzheng of the Qing Dynasty in 1729. It was because of the abysmal effects associated with the drug that recreational use of opium had also been banned in Europe. Historically, opium had been rather scarce in China. The scarcity of the narcotic in China consequently drove the price way up. The British East India Company was able to establish a monopoly on the opium trade and in-turn they were able to deal it exclusively to the east (Elman 2006, 101). The opium market was of substantial economic significance to the British. The profits that were flooding in from the commodity contributed considerably to the revenue of the British Imperialized India. The British government also benefitted from the tax that was levied on the tea that was being imported from China at the same time. Additionally, the merchants who traded the opium obviously benefitted as well. The opium was trafficked primarily by the British East India Company into China (Elman 2006, 100). The result, a severe illegal opium trade had spawned and the Europeans were directly profiting at the expense of the Chinese (Elman 2006, 6).

Essentially, opium sales to China were profitable for everyone, except the Chinese. Ultimately, the Europeans introduced millions of Chinese people to the highly addictive narcotic. During the 1820's many Chinese became addicted to the European supplied opium, it had become an epidemic. "From 1823 to $1824, \$ 8,515,100$ of opium was shipped to China" (Tagliacozzo \& Chang 2011, 94). The people of China had become addicts and quickly began trading their countries precious resources away for drugs.

From the 1820s forward, British trade with China was in surplus. The enormous expenditure of Chinese silver used to purchase the illegal opium greatly exceeded the amount that the merchants spent on Chinese tea. From 1828 through 1836 more than $\$ 38$ million poured out of Qing China to import the illegal drug (Elman 2006, 100-101). For the first time an imbalance of trade had formed and China was on the losing end. The Chinese economy suffered tremendously due to the influx of opium being supplied by the Europeans.

The Qing emperor understood it was imperative to stop the British merchants from continuing to poison his people. Emperor Qianlong gravely overestimated diplomacy. 
The British did not rely on any form of tribute system. Europeans, specifically the British were primarily concerned with nation building by any means. Diplomacy would prove ineffective when dealing with the European Imperialists. Emperor Qianlong did not completely grasp the extent to which the Industrial Revolution had propelled the Europeans naval warfare capabilities (Elman 2005, 254-255). Had the emperor completely understood the consequences of not opening up China to trade with the British, he more than likely would have been inclined to ease his policies regarding the expansion of international trade.

\section{THE OPIUM WARS}

From a military standpoint, the Chinese were not prepared to go to war with the British. The Industrial Revolution that had taken place in the West severely handicapped the Chinese navy. The British naval ships had been seriously overhauled and the upgrades would swiftly overwhelm the Qing fleet. The Chinese fleet was largely a coastal navy which was used primarily to ward off local marauders and defend against pirates (Elman 2005, 193). The success of the British was predominantly attributed to superior naval technology. The aggression and imperialist nature of the British had led them to utilize technology to develop weapons capable of conquest. The British had superior ships, artillery, rifles, and they were fueled by greed. Jeffery Needham pointed out in Science and Civilisation in China that the Chinese had discovered paddle-wheel boats and ships as far back as the first century (Needham 2004, 218-219). That specific technology had not been recorded in Europe until many years later. Low and behold, it was the shallow draught iron paddle-steamer, named the Nemesis that would end up terrorizing the Pearl River delta. The iron hulled Nemesis destroyed Chinese fortifications and naval vessels at will. The British fleet simply overwhelmed the Chinese. A discovery contributed by the Chinese centuries earlier had been improved upon by the Europeans and used as an instrument of war. By the end of the First Opium War it had become obvious to the Qing Emperor that the technological advances made by the Western military had somehow managed to quickly surpass his country's defensive capabilities.

In order to end the bloodshed, the Chinese were forced by the British to agree to some severely lopsided peace terms. The terms were highly favorable for the British (Elman 2006, 101). Being so heavily outgunned, the Chinese Emperor had little choice but to agree to the lopsided terms set by the British and sign the Treaty of Nanking. There were four major consequences of the First Opium War. The first peace term of The Treaty of Nanking involved China giving Hong Kong to England. Secondly, five ports, including Canton and Shanghai, were required to be open to trade as well as permanent residence (Elman 2005, 286). Import tariffs were then reduced to a maximum of $5 \%$. Possibly the hardest pill for China to swallow was the extraterritoriality clause that allowed all foreigners who resided in China to be exempt from Chinese laws (Tagliacozzo \& Chang 2011, 380-381). The extraterritorial concessions surrendered local sovereignty over to the British Crown. The British, by way of military strength, forced China to open its country up to the opium trade in the 1840's. China also experienced social turmoil in the form of the bloody Tai Ping rebellion, and was unable to prevent foreign domination of its trade. By the end of the 19th century, England, Germany, Russia, Japan, and the United States had all obliged China to trade with them. Russia occupied Manchuria and Port Arthur, Japan was in Korea, Germany was 
in the Shantung peninsula, and the British were in Hong Kong.

The Second Opium War was in many ways an unavoidable sequel to the first war. The Chinese were not ready to implement the terms of the Treaty of Nanking largely because they viewed it as being unfair. The biggest problem for China was that the Treaty of Nanking did not address the opium issue. Opium smuggling continued, and this only increased Chinese resentment of the foreigners. British merchants were unhappy because they did not see a huge rise in profits from trade with China after the First Opium War like they had anticipated. They attributed their displeasure to the Chinese purposely taking too long to implement the newly agreed upon policies (Encarta 2003, 321-322). Still, clever Chinese diplomacy and a number of other political distractions kept the conflict from further manifesting itself for a number of years. War with the British inevitably ensued and the superior power of the Europeans and their refusal to compromise culminated in the signing of the Treaty of Tianjin. This time the British would require among other things that China open up ten new ports to foreign trade. The Chinese resistance ultimately led to an 1860 European invasion of the Chinese capital and the burning of the Summer Palace. British leaders required the Convention of Beijing on the defeated Chinese, establishing once and for all the right of foreign diplomatic representation in China's capital (Elman 2006, 160-161). Many restrictions on foreign travel within China were removed, and missionaries received the right to work and even own property in China (Elman 2005, 357-358). The opium trade, which spurred the entire conflict, was finally legalized.

The Opium Wars are extremely important to China's modern economic history. "China itself was forced to give special access (the 'unequal treaties') to certain European countries" (Kang 2010, 160). The two wars, and the unfair peace treaties that Europe had imposed on China, weakened their political, social and economic structure (Tagliacozzo \& Chang 2011, 96-97). The Opium Wars were a pivotal point in both the European and Chinese economies. The British and Western penetration and colonization of China had spawned a whole new socioeconomic class. Wealthy Chinese merchants imported British goods and enabled the annexation of local markets and resources. The greed of the British Imperialists forced unprecedented levels of exploitation and taxation on the growing population of Chinese peasants and workers. China's rulers were obliged to pay the war debts and finance trade deficits imposed by the treaties drafted by the Western imperial powers. The government was essentially forced to over tax the poorest of poor Chinese. This drove countless peasants to starvation and often insurrection. The speed at which the Europeans were able to prosper forced the Chinese to reevaluate the way that their country was being governed. The Opium Wars led the Chinese to begin "a new era of reform known as Self-Strengthening" (Elman 2006, 161). The Qing dynasty recognized that China had fallen behind and that they must evolve in order to survive.

Historically, China had based its economic dominance on non-interference in the internal affairs of its limited trading partners. The teachings of Confucius and their regional tribute system had previously afforded the Chinese people peace and economic prosperity. In sharp contrast, the Europeans, specifically the British imperialists, intervened violently in China, rearranging local economies to suit the needs of their empire. The British eliminated economic competitors and monopolized industries (Tagliacozzo \& Chang 
2011, 126). Within a few decades of the colonial powers arriving from Europe the tribute system and Confucian order, both of which had been a monumental part of Chinese society for over two thousand years had collapsed (Kang 2010, 159). The British imposed their will on the people of China and by force they eventually seized control of local political, economic and governmental establishments. Chinese bureaucrats and wealthy merchants sought to appease the British Imperialists and were able to convince the emperor to grant debilitating extraterritorial concessions that, detrimental to Chinese manufacturers, opened its markets to the world. Adding to the strains that they had by this time put on the Chinese economy, the British, guided by greed would continue to cause internal rivalries and revolts that would continue to destabilize the collapsing country throughout the $19^{\text {th }}$ century.

Less than a century after the Opium Wars had ended, China, assisted by the Europeans, had plummeted and was no longer a dominant economic world power. The main arterial trading ports were controlled by European imperial officials and the rural areas were usually governed by corrupt and ruthless warlords.

"Between 1841 and 1979, East Asia experienced interstate wars, colonization, anticolonial independence wars, struggles with state building, domestic insurgencies, ethnic violence, the cold war and a massive U.S. military, economic, and social presence” (Kang 2010, 160).

China had been reduced; it had transformed relatively quickly to become a fledgling nation with a massive impoverished population comprised of drug addicts. The once prideful, Chinese, had been broken. The people of China were humiliated and ashamed of what had been allowed to transpire. It is my contention that opium and violence were among the principal reasons that the Europeans were so successful in turning the economic tables on the Chinese. Another central cause was the social structure (Confucianism and the tribute system) that had existed in China for so long. This social structure is perhaps why China as a nation, did not adapt effectively to the challenges posed by the Western nations after the Industrial Revolution.

\section{COMMUNISM}

Imperialism ended in China when a revolt that began in late 1911 was able to successfully overthrow the Qing dynasty. The Republic of China began to take shape and by 1912 the Chinese Nationalist Party emerged. The Nationalist Party could not maintain control and lost power by 1916. The lack of a unified government allowed warlords to thrive and the rest of the country to struggle. Despite once being a world power, by the late 1920's China was not even a unified country. By 1921 civil unrest caused by the Treaty of Versailles led the people of China to a revolutionary movement. China was formally unified under the Chinese Communist Party and all other names of communist groups were dropped in July of 1921 (Cultural China.com). The Communist government was able to abolish the extraterritorial privileges granted by the European imperialists. China was able to experience modest economic growth up until the war with Japan escalated in 1937 (Brandt \& Rawski 2008, 267-269).

The People's Republic of China formed in October 1949. The Communist party, then unified under Mao Zedong began the process of reforming China, which many believe was unsuccessful. The Communist Party's organizational discipline and propaganda, combined with Mao's loyal soldiers formed a strong governmental structure. Mao's system of government was able to infiltrate deeper 
than the imperial system, into China's countryside and urban areas (Vogel 2011, 13).

China, led by Mao, was able to lower inflation, restore fiscal balance and revive the money economy (Perkins 1966). The economy in Mao's China, despite short disruptions because of the Great Leap Forward and the Cultural Revolution had in deed made some progress. The World Bank estimated that between 1950 and 1975, China demonstrated (in certain areas) remarkable improvement with an average annual growth of 4.2 percent per capita GNP (Brandt \& Rawski 2008, 19-21). While this was positive, it might not have painted a precise picture of just exactly how well the people of Mao's Soviet style China were in fact, actually doing.

Even though China was a low-income country, they chose to pursue a strategy of high science and technology. Even before Mao, Chinese scholar Kang Youwei and other reformers had been aggressively pursuing the industrialization of China through science and technology.

\begin{abstract}
"In his 1905 essay on industrialization, for instance, Kang emphasized that China, like Japan, needed to master mining, industry, and commerce. Because machines had augmented the power of European states and enhanced the welfare of the people" (Elman 2006, 202).
\end{abstract}

Many countries had been of the mind-set that pursuing an industrial oriented society would lead to quicker development than that of an agricultural one. At the time, economists often recommended political leaders to direct all investments toward industry. Agriculture, despite historically being a vital component in the countries prior success, did not receive equal attention from the government. Countries that followed that advice usually experienced brief gains, followed by failed development efforts (Brandt \& Rawski 2008, 467; see Timmer).

China modeled their national system after the Soviets organizational structure of research and development (Brandt \& Rawski 2008, 191; see Naughton). Growth during 1958-1978 was primarily made possible by the high rising rates of capital accumulation. That accumulation simply replaced productivity enhancement as the dominant contributor to GDP growth. Research by Lardy (1984), Bramall (1989) among others showed that China's rural majority were not able to experience much if any improvement in their living standards (Brandt \& Rawski 2008, 842).

The inability to significantly improve the quality of living standards for the people of China clearly indicated the ineffectiveness of Mao's innovation system. A leading cause had been attributed to the total factor of production in the agricultural sector. In 1979 the total factor of production was lower than it had been previously in 1952, an important point that was highlighted by Chow (1989). During a similar period, a contrasting study of the industrial sector showed slight growth (Brandt \& Rawski 2008, 86-88). It many peoples opinion, Mao focused too much of China's resources on industrial initiatives. The government needed to prioritize and focus even more of its attention, like it had done so effectively in the past, on agriculture.

The neglect of rural investment led agricultural productivity to be low, which inflated the cost of food. Property rights, weak incentives for farmers and the lack of markets all resulted in poor agricultural output. The Chinese infrastructure and lack of transportation prevented food from getting from the farms to people's homes before it spoiled. Poor management of the land simultaneously exhausted the soil and the water supply. The low productivity of China's 
agricultural industry resulted in severe food supply shortages that manifested into famines. The country, while indicating many positive signs of growth, had a gigantic problem on its hands. The country's food supply was an obstacle; that, given China's past agricultural successes and innovation should have been a relatively easy to situation to overcome. In order to improve the economy, Mao and the rest of his party needed to immediately address China's food supply crisis. Instead, according to Ezra Vogel, Mao chose a different course of action, "an ill-advised utopian debacle that led to massive food shortages and millions of unnatural deaths" (Vogel 2011, 13). Sadly, 3040 million Chinese died of starvation in a short span of only three years, from 1959-1961 (Brandt \& Rawski 2008, 191-192). The country would eventually try to tackle this crisis from two different angles. They would look to produce more food, for less people.

China would once again need to restructure its governmental system in order to successfully transition back to prosperity. Mao's Soviet style Communism promoted isolationism and had been suppressing China's progress. "When China's leaders made the decision to initiate economic reform in 1978 , the top leaders, especially Deng Xiaoping, understood that their system had been profoundly damaged by the final twenty years of Maoism." (Brandt 2008, 93, see Naughton). The new leaders intended to bring the economy back to life and restore order to the broken socialist political system.

Deng Xiaoping thought that in order to permanently revitalize China, among other reforms, a shift in the countries education system was needed. If the country were going to become competitive in the global economy, they would need to focus on academics. Mao's previous system regarding university entrance exams would need to be revised. Mao's eventual successor Deng Xiaoping, believed that the most qualified students should be admitted into the university, period. Mao's earlier methodology of "proper class background" had allowed wealthy imbeciles into the university instead of intelligent peasants (Vogel 2011, 205).

\section{CAPITALISM}

In 1980 China's government, headed by Deng Xiaoping, began to undergo a dramatic change in its economic strategy: Over the next thirty or so years, China opened the country to extensive foreign investment. Deng believed that competition from foreign companies would force Chinese businesses to become stronger (Vogel 2011, 476). Chinese industries were finally allowed to privatize. This privatization in turn, set in motion a process of income concentration founded on a measured strategy of reconstructing a dominant economic class connected to overseas capitalists. Severe competition was created across many industries. "A large number of new (mostly small) firms were founded in most transitional economies" (Brandt \& Rawski 2008, 68,). The profit erosion that ensued because of competition urged many existing enterprises to search for revolutionary processes and product innovations in order to ensure their survival.

The Chinese government re-directed enormous public subsidies to encourage large amounts of capitalist growth by dismantling its tired national system of free public education and health care. They also ended subsidized public housing for hundreds of millions of peasants and urban factory workers; deciding instead to provide funding to real estate investors for the construction of private apartments and office high-rise buildings (Brandt \& Rawski 2008, 737). China's new capitalist approach as well as its rapid growth 
was founded on the insightful structural modifications and substantial investments made possible by Mao's regime. The boom in China's private sector was established by the huge public outlays that had been made since 1949. It was Mao's initial investment in China's infrastructure and industry that paved the way for capitalisms success. Through ample research many scholars have determined China's rapid economic growth initially began closer to 1950 than 1980 . Also, that growth was based on the development of its internal market; it's rapidly growing corps of scientists, skilled technicians and laborers. Additionally, the societal structure which both protected and promoted the working class and peasantry were products also yielded from Communism. However, if the once great nation was going to survive in the global economy, the country desperately needed to embrace the necessary economic reforms.

\section{REFORM}

China's earliest and most important economic reform policy was the household responsibility system (HRS) that was introduced to the agricultural industry. "Starting with the restoration of household agriculture in the late 1970's, China has implemented a long sequence of increasingly coherent, focused, but still partial, gradual, and yet unfinished economic reforms" (Brandt \& Rawski 2008, 20). HRS was implemented in rural areas between 1978 and 1983 in an effort to increase agricultural output. The Mao system of commune style farming that had been allowed to decimate the agricultural industry would be replaced with a more productive incentive based system (Brandt \& Rawski 2008, 169-170). During the reform era, China was able to increase its food production to the point that they were able to become an exporter (Brandt \& Rawski 2008, 469-471). "Once the reform began, every possible metric confirms that China's farm sector surpassed results achieved during the previous three decades by enormous margins" (Brandt \& Rawski 2008, 475). Food production had finally outpaced the growth in population. The immediate impact that the reform policies had created, instilled a higher level confidence of the people in the government.

In an effort to manage its population growth, Chinese leadership introduced a policy in 1979 that would allow couples in certain regions to have only one child. The leadership firmly believed that the sudden rapid growth in population that had taken place over the prior few decades had been the root cause of China's turbulent economic times (Brandt \& Rawski 2008, 138). The tempered growth in China's population had a positive impact on the overall productivity. During the course of a typical human's lifespan, people are only productive during the middle of their lives. When people are young or old, they obviously consume more than they are able to produce (Brandt \& Rawski 2008). China's one-child policy temporarily solved a crisis, but it at the same time was creating what would eventually manifest into a whole new problem. However, the Chinese leadership, through decisive reform was able to manage their way out of the initial crisis; they will do the same with the new one.

Modern China's rise to becoming a world economic power is based on its enormous productive capacity. Output per worker has tripled in China between 1980 and 2004. Only India has come close to being able to compete with China's productivity (Brandt \& Rawski 2008, 26-27).

In 1978 China had only 12 firms directly controlled by the Ministry of Foreign Trade, which were authorized to conduct foreign trade. By 2001 that number had ballooned to over 35,000 (Lardy 2002, 40-42). "When Deng became preeminent leader in 1978, China's 
trade with the world totaled less than $\$ 10$ billion; within three decades, it had expanded a hundredfold” (Vogel 2011, 697). Regarding trade as well as investment, China has always operated under a strict policy of noninterference when it comes to the internal affairs of its trading partners. Unlike the West, China did not constantly participate in wars for natural resources; instead its government chose to enter into lucrative contractual agreements for its desired commodities.

China has powerful trading, financial and investment networks throughout the world. Additionally, China has a host of powerful economic partners which share a vested interest in their continued success. These partnerships have become essential for the sustained growth of many countries throughout the developing world. "China's adoption of one of the developing world's most open trade and FDI regimes stands as one of the most significant accomplishments of the reform era" (Brandt \& Rawski 2008, 676). While foreign capital began to profit in China, it did so within the agenda of the government's priorities and regulations. The government's dynamic export strategy combined with an ingenious monetary policy has led to giant trade surpluses. These surpluses have afforded China to become one of the world's largest creditors, especially for United States debt. In order to maintain its position among these industries, China must regularly procure enormous amounts of raw materials. In order to facilitate the continued procurement of these materials, China has large-scale foreign investments and trade agreements with agromineral export countries from around the world. China has replaced the United States and Europe as the main trading partner in many countries.

China's ruling politicians at first, more or less embraced the idea of pirating technical intellectual property and accessing overseas markets from foreign firms in exchange for providing cheap, labor that was well below the going market rate. The sustained growth in China's manufacturing sector has been a result of highly concentrated public investments, high profits, technological innovations and a wellprotected domestic market (Brandt \& Rawski 2008, 24). China's leadership realized that innovation needed to be a priority. They understood that technological advances were going to play a vital role in guaranteeing the future success and sustainability of their economy. By 1985 China had restructured its patent laws and identified its shortcomings with dealing with intellectual property rights (Brandt \& Rawski 2008, 294). In December of 2001 China was accepted into the World Trade Organization and officially recognized as a valued partner in the world's economic community.

Throughout history Chinese leadership has repeatedly demonstrated that it prefers diplomacy to military strength. "Throughout the 1980's, then, the Chinese government decreased the proportion of the budget going to the military" (Vogel 2011, 541). Deng Xiaoping preferred to keep military expenditures down in order to channel more resources to advance the civilian economy (Vogel 2011, 545). As a result of that investment, China has been able to improve its GDP on an average of 9.5 percent annually between 1978 and 2005 (Brandt \& Rawski 2008, 878). On the other end of the spectrum, the United States military spending is more than five times greater than China's and its economy has stalled (Shah, 2012). It appears that once again China has chosen economic superiority over military power. China, with the second largest economy in the world is in glaring contrast to the largest economy, the United States, where an enormous military force continually erodes its 
civilian economy. The Chinese have decided to invest the majority of their resources in their people's futures and not in foreign wars.

\section{CONCLUSION}

It is my contention that a variety of Chinese contributions expedited Europe's prolific economic development and aided in its expansion. Perhaps with the assistance of innovations derived from China, the European economy was able to forge ahead of China's economy. In addition to the Europeans developments, there were several other contributing factors that led to the fall of the Chinese economy. Though modern opinion is beginning to change, many historians, especially European historians accredit the British imperial dominance of China to the technological supremacy of the Europeans. It is true that modern science and technology propelled the Europeans ahead of China. But, the contributions made solely by China as well as knowledge achieved by teamwork amongst both the Europeans and Chinese alike is what bridged the gap for the Europeans to propel ahead (Needham 2004, 231). It is my contention that opium and violence were among the principal reasons that the Europeans were so successful in trading economic places with the Chinese. Another central cause was the social structure (Confucianism and the tribute system) that had existed in China for so long. This social structure is perhaps why China as a nation, did not adapt effectively to the challenges posed by the Western nations after the Industrial Revolution. The examples given should help to explain that a distinct correlation does in fact exist between Europe's rapid economic growth and the fall of China during the $18^{\text {th }}$ century. In spite of substantial adversity, China has reemerged as one of the most dominant economic forces in the world. China has quickly earned the position as the world's second largest economy and is poised for much continued success. Modern China, as a world power, is exceptionally stronger than it was. 


\section{References}

1. Brandt, L., \& Rawski, T. G. (2008). China's Great Economic Transformation. New York: Cambridge University Press.

2. Brandt, Loran, Chang-tai Hsieh, and Xiaodong Zhu. "Chapter 19/Growth and Structural Transformation in China." Ed. Thomas G. Rawski. China's Great Economic Transformation. Ed. Loren Brandt. New York: Cambridge UP, 2008. 683-725. Print.

3. Branstetter, Lee, and Nicholas Lardy. "Chapter 16/China's Embrace of Globalization." Ed. Thomas G. Rawski. China's Great Economic Transformation. Ed. Loren Brandt. New York: Cambridge UP, 2008. 633-77. Print.

4. Braudel, Fernand. "Civilization and Capitalism, 15th-18th Century, Vol. III:." Google Books. New York Harper and Row 1982, Feb. 2009. Web. 12 Jul. 2012. <http://books.google.com/books/about/Civilization_and_Capitalism_15th_ 18th_Ce.html?id=xMZI2QEer9QC $>$.

5. Cai, Fang, Albert Park, and Yaohui Zhao. "Chapter 6/The Chinese Labor Market in the Reform Era." Ed. Thomas G. Rawski. China's Great Economic Transformation. Ed. Loren Brandt. New York: Cambridge UP, 2008. 167-211. Print.

6. Cultural China. "History of the Communist Party of China." History of the Communist Party of China. Cultural China, n.d. Web. 03 Jun. 2012. <http://history.cultural-china.com/en/34History780o.html>.

7. Elman, B. A. (2005). On Their Own Terms Science in China, 1550-19oo. Cambridge, Massachusetts, and London, England: Harvard University Press.

8. Elman, B. A. (2006). A Cultural History of Modern Science In China. Cambridge, Massachusetts, and London, England: Harvard University Press.

9. Hsu, Immanuel C.Y. "'Macartney Mission, 1793". The Rise of China." Macartney Mission. New York. Pp155-163, 1995. Web. 15 Jul. 2012. <https://www2.stetson.edu/secure/history/hy10430/macartneymission.ht $\mathrm{ml}>$.

10. Hu, Albert G.Z, and Gary H. Jefferson. "Chapter 9/Science and Technology in China." Ed. Thomas G. Rawski. China's Great Economic Transformation. Ed. Loren Brandt. New York: Cambridge UP, 2008. 286-332. Print.

11. Huang, Jikun, Keijiro Otsuka, and Scott Rozelle. "Chapter 13/Agriculture in China's Development: Past Disappointments, Recent Successes, and Future Challenges." Ed. Thomas G. Rawski. China's Great Economic Transformation. Ed. Loren Brandt. New York: Cambridge UP, 2008. 467502. Print. 
12. Kang, D. C. (2010). East Asia Before The West. New York: Columbia University Press.

13. Lockard, C. A. (2009). Southeast Asia in World History. New York: Oxford University Press, Inc.

14. McHenry, R. (1992). The New Encyclopedia Brittanica. Chicago: Brittanica Inc.

15. Naughton, Barry. "Chapter 4/ A Political Economy of China's Economic Transition." Ed. Thomas G. Rawski. China's Great Economic Transformation. Ed. Loren Brandt. New York: Cambridge UP, 2008. 68-87. Print.

16. Needham, J. (2004). Science \& Civilization in China Volume 7: The Social Background, Part 2, General Conclusions and Reflections. New York: Cambridge University Press.

17. SACU. "Religion in China." Chinese Religions. Society for Anglo-Chinese Understanding, 3 Nov. 2001. Web. 29 Jul. 2012. <http://www.sacu.org/religion.html>.

18. Shah, Anup. "World Military Spending." Global Issues. N.p., 6 May 2012. Web. 01 Aug. 2012. <http://www.globalissues.org/print/article/75>.

19. Svejnar, Jan. "Chapter 3/ China in Light of the Performance of Transition Economics." Ed. Thomas G. Rawski. China's Great Economic Transformation. Ed. Loren Brandt. New York: Cambridge UP, 2008. 91-130. Print.

20. Tagliacozzo, E., \& Chang, W.-C. (2011). Chinese Circulations. Durham, NC; London, England: Duke University Press.

21. $\quad$ "The Chinese Revolution of 1911." History of the Communist Party of China. U.S. Department of State, n.d. Web. o1 Aug. 2012. <http://history.culturalchina.com/en/34History780o.html>.

22. Vogel, E. F. (2011). Deng Xiaoping and the Transformation of China. Cambridge, Massachusetts, and London, England: The Belknap Press of Harvard University Press. 